\section{Changes in serum metabolic hormone levels after glucose infusion during lactation cycles in Holstein cows}

\author{
Aliasghar Chalmeh, Ali Hajimohammadi, \\ Soheil Bagheri, Mohammad Jalali \\ Department of Clinical Sciences, School \\ of Veterinary Medicine, Shiraz University, \\ Iran
}

\section{Abstract}

Negative energy balance can impair the metabolism of high producing dairy cows and supplying the glucose, as an energy source; can prevent the metabolic disorders in these animals. Hence, we hypothesized that bolus intravenous glucose administration may change the concentrations of metabolic hormones in order to prevent and control of metabolic dysfunctions of dairy cows. Twenty five multiparous Holstein dairy cows were divided to 5 equal groups containing early, mid and late lactations, far-off and close-up dry periods. All cows were received dextrose $50 \%$ intravenously at $500 \mathrm{mg} / \mathrm{kg}, 10 \mathrm{~mL} / \mathrm{kg} / \mathrm{h}$. Blood samples were collected from all animals prior to and 1,2, 3 and 4 after dextrose 50\% infusion and sera were separated to determine glucose, triiodothyronine (T3), thyroxine (T4), serum free T3 (fT3), free T4 (fT4), cortisol and insulin like growth factor-1 (IGF-1). The decreasing pattern of $\mathrm{T} 3$ concentration was detected in all studied animals following intravenous glucose infusion $(\mathrm{P}<0.05)$. The significant increasing pattern of T4 levels was seen in early and mid lactation cows after glucose administration $(\mathrm{P}<0.05)$. The significant decreasing pattern of IGF-1 was detected in mid and late lactations and far-off dry groups $(\mathrm{P}<0.05)$. There were no significant alterations in fT3, fT4 and cortisol concentrations following glucose infusion in all experimental groups. In conclusion, bolus intravenous glucose infusion could influence the metabolic hormones in high producing Holstein dairy cows. Alterations of metabolic hormones following bolus intravenous glucose administration indicated that glucose is an important direct controller of metabolic interactions and responses in dairy cows during different physiological states.

\section{Introduction}

Glucose blood concentration is considered to be a direct indicator of energy balance in the organism. The glucose has an important role in high producing dairy cows because certain vitally important cell types and metabolic pathways have to rely on glucose as the only energy substrate. ${ }^{1}$ In ruminants blood glucose regulation differs from the regulation in most monogastric animals. In ruminants, volatile fatty acids from the gastrointestinal tract are the major energy source rather than direct sources of glucose. Within the ruminants, high producing dairy cows occupy a special position regarding the glucose metabolism which is related to increases in energy requirements driven by both fetal needs and lactogenesis. ${ }^{2}$ Primary homeoretic adaptation of glucose metabolism in the lactating dairy cows leads to an increased gluconeogenesis in the liver to direct glucose to the mammary gland for lactose synthesis. ${ }^{3}$ If the degree of gluconeogenesis does not satisfy increased needs in glucose of dairy cows in the lactation periods, hypoglycaemia, ketonemia and ketonuria likely occurs. 4

A dairy cow has several and different physiological states during life. A marked disproportion between dry matter intake, milk yield level and fetal development in gravid uterus is related to negative energy balance takes place during some states. ${ }^{5-7}$ The unique transition from pregnancy non-lactating to non-pregnancy lactating status can drive metabolism to extremes and the glucose metabolism has a key role to prevent the metabolic dysfunction and diseases. 2 The changes in circulating concentrations of metabolic hormones and nutritionallyrelated metabolites are important signals of the metabolic state of the animal especially on the adequacy of nutrient supply in relation to nutrient utilization. ${ }^{8}$ Hence, it may be suggested that metabolic hormones in each metabolic state of dairy cows are different from other states. The hormonal activity of thyroid gland has an important role in the transitional period for determining the cell metabolism intensity, metabolism of lipids and carbohydrates and lactation course itself by its thyroid hormones.9,10 A positive correlation was established between thyroid hormones in the blood and energy balance and a negative one between concentrations of these hormones in the blood and milk production. 8,10 Under the conditions of a negative energy balance and of high lipomobilization, the concentrations of thyroid hormones in the blood were significantly lower in transitional period. 9,11 Another regulator of glucose in ruminants is cortisol, which acts to increase gluconeogenesis from amino acids. In starving ruminants the gluconeogenesis is maintained by elevated levels of glucocorticoids. ${ }^{12}$ In lactating ruminants the rate of hepatic gluconeogenesis and the relative concentrations of glycogenic precursors regulate the level of milk production. ${ }^{13}$ The flow of glucose into the mammary gland is not
Correspondence: Aliasghar Chalmeh, Department of Clinical Sciences, School of Veterinary Medicine, Shiraz University, P.0. Box, 71345, Shiraz, Iran.

Tel.: +98.711.613.8700 - Fax: +98.711.228.6940.

E-mail: achalmeh81@gmail.com

Key words: Glucose metabolism; metabolic hormones; negative energy balance; Holstein dairy cows.

Acknowledgments: Hormonal analysis was kindly performed with the cooperation of Professor Saeb Specialized Hormone Laboratory, Shiraz, Iran.

Contributions: the authors contributed equally.

Conflict of interest: the authors declare no potential conflict of interest.

Received for publication: 13 January 2015.

Revision received: 8 February 2015.

Accepted for publication: 10 February 2015.

This work is licensed under a Creative Commons Attribution NonCommercial 3.0 License (CC BYNC 3.0).

(C) Copyright A. Chalmeh, et al., 2015

Licensee PAGEPress srl, Italy

Veterinary Science Development 2015; 5:5808

doi:10.4081/vsd.2015.5808

dependent of insulin in ruminants. ${ }^{14}$ Insulin like growth factor-1 (IGF-1) also considered as a metabolic hormone that bind to insulin receptors and has a key role in metabolism of glucose in high producing dairy cows. ${ }^{15}$

Since the cows have several metabolic sates whit disproportions between energy input and output, the aim of the present study was to reveal the effect of glucose, as an energy source, on metabolic hormones levels at each state. Hence, the changing pattern of thyroid hormones, cortisol and IGF-1 was followed after bolus intravenous glucose administration in high producing Holstein dairy cows at different metabolic states and these changes were compared together.

\section{Materials and Methods}

\section{Animals}

The present experiment was performed after being approved by the Ethics Committee of the School of Veterinary Medicine, Shiraz University. This research was carried out at winter 2014 on 25 multiparous Holstein dairy cows from a high producing industrial dairy farm around Shiraz, Southwest Iran. These cows were housed in open-shed barns with 
free access to water and shade. The total mixed rations were formulated and prepared for all animals according to National Research Council (NRC) requirements. At this farm, a dry period of 60 days has been considered. Milk production was about $10,000 \mathrm{~kg}$ for year, an average of 3.6 of milk fat \%, and 3.3 of milk protein $\%$. All the animals were clinically healthy, had not history of debilitating disease, and free from internal and external parasites due to routine antiparasitic programs at this farm. Body condition score (BCS) of these animals were estimated based on 0 to 5 system. Cattle were divided to 5 equal groups containing early $(30.2 \pm 5.7$ days after calving, with $3.25 \pm 0.25 \mathrm{BCS}$ and $590.00 \pm 26.45 \mathrm{~kg}$ body weight), mid (108.1 \pm 8.4 days after calving, with $3.25 \pm 0.25 \mathrm{BCS}$ and $586.00 \pm 40.98 \mathrm{~kg}$ body weight) and late lactations (184.5 \pm 5.7 days after calving, with $3.5 \pm 0.25$ BCS and $616.00 \pm 27.01 \mathrm{~kg}$ body weight), far-off $(281.9 \pm 5.4$ days after calving, $228.4 \pm 8.6$ days of pregnancy, with $3.5 \pm 0.25$ BCS and $632.00 \pm 21.67 \mathrm{~kg}$ body weight) and close-up dry periods (312.1 \pm 8.3 days after calving, $255.6 \pm 6.3$ days of pregnancy, with $3.5 \pm 0.25$ BCS and $646.00 \pm 26.07 \mathrm{~kg}$ body weight).

\section{Bolus intravenous glucose adminis- tration}

All experiments were done an hour after morning meal, at $6 \mathrm{AM}$, approximately. A 14gauge 5.1-cm catheter was secured in the right jugular vein and used for blood samplings and dextrose infusions. A blood sample was taken immediately after catheterization, and dextrose 50\% (Zoopha ${ }^{\circledR}$, Parnian Co., Tehran, Iran) was administered at $500 \mathrm{mg} / \mathrm{Kg}$, during 15 minutes, subsequently. ${ }^{2}$ Blood samples were collected from all cows through the fixed catheter prior to and 1, 2, 3 and 4 after dextrose $50 \%$ infusion in plain tubes.

\section{Serum biochemical analyses}

Immediately after blood collections, sera were separated by centrifugation for $10 \mathrm{~min}$ utes at $3000 \mathrm{~g}$ and stored at $-22^{\circ} \mathrm{C}$ until assayed. Glucose was assayed by an enzymatic (glucose oxidase) colorimetric method (ZistChem ${ }^{\circledR}$, Tehran, Iran). Serum triiodothyronine (T3) concentrations were determined using a competitive enzyme immunoassay kit (Padtan Elm Co., Tehran, Iran). The intra- and inter-assay CVs of the assays were $12.6 \%$ and $13.2 \%$, respectively. The sensitivity of the test was $0.2 \mathrm{ng} / \mathrm{mL}$. Serum thyroxine (T4) concentrations were measured using a competitive enzyme immunoassay kit (Monobind Inc., Lake Forest, USA). The intra- and inter-assay CVs of the assays were $3.0 \%$ and $3.7 \%$, respectively. The sensitivity of the test was $0.4 \mathrm{mg} / \mathrm{dL}$. Serum free T3 (fT3) and free T4 (fT4) concentrations were determined by the fT3 and the fT4 ELISA kits (DiaPlus Inc., San Francisco, USA). The intra- and inter-assay CVs of the fT3 assays were $4.1 \%$ and $5.2 \%$, respectively. The sensitivity of the test was $0.05 \mathrm{pg} / \mathrm{mL}$. The intra- and inter-assay CVs of the fT4 assays were $4.5 \%$ and $3.7 \%$, respectively. The sensitivity of the test was $0.05 \mathrm{ng} / \mathrm{dL}$. Serum cortisol concentrations were determined by Enzyme
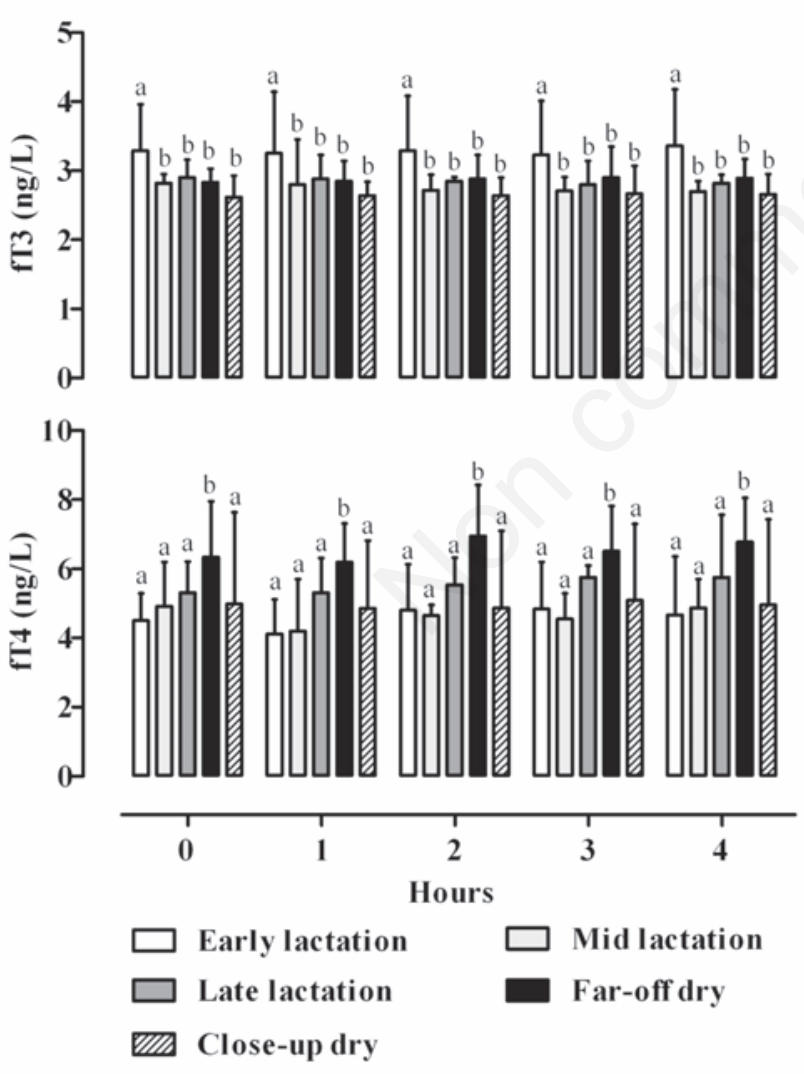

Figure 1. Alterations (mean \pm standard deviation) of serum fT3 and fT4 concentrations following bolus intravenous glucose administration (dextrose $50 \% ; 500 \mathrm{mg} / \mathrm{kg}$ during 15 minutes) at different lactation cycles in Holstein cows (each group contains 5 cows). Different letters indicate significant differences among groups in each hour $(\mathrm{P}<0.05)$.
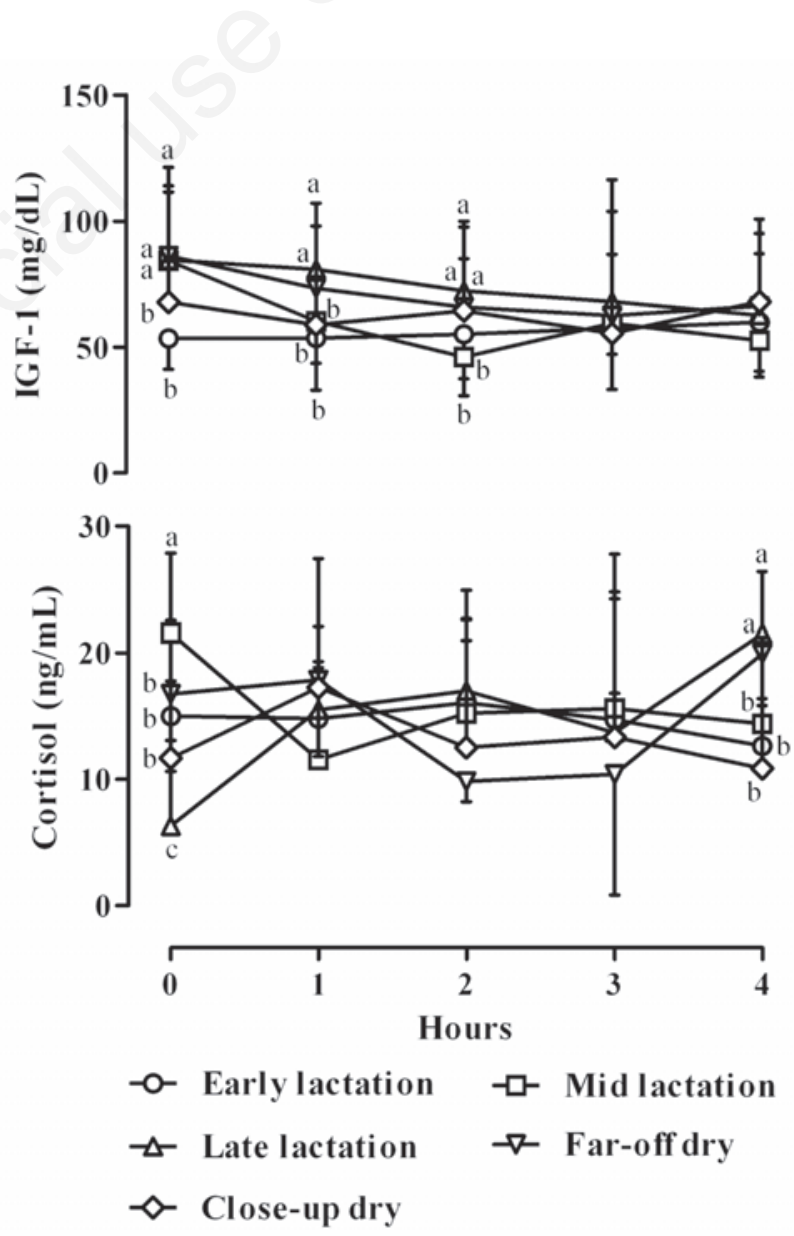

Figure 2. Alterations (mean \pm standard deviation) of serum IGF1 and cortisol concentrations following bolus intravenous glucose administration (dextrose $50 \% ; 500 \mathrm{mg} / \mathrm{kg}$ during 15 minutes) at different lactation cycles in Holstein cows (each group contains 5 cows). Different letters indicate significant differences among groups in each hour $(\mathrm{P}<0.05)$. 
Immunoassay Colormetric method (AccuBind $^{\circledR}$ ELISA kit; Monobind Inc., CA, USA). The sensitivity of the test was $0.25 \mu \mathrm{g} / \mathrm{dL}$. Serum levels of IgF-1 were evaluated by ELISA kit (ImmunoDiagnosticSystem ${ }^{\circledR}$ ) with the sensitivity equal to $3.1 \mu \mathrm{g} / \mathrm{L}$.

\section{Statistical analyses}

All data are presented as mean \pm standard deviation (SD). Differences among the averages of concentrations of different serological factors at similar hours in all groups were analyzed by one-way ANOVA and the least significant difference (LSD) test was used to find differences. Repeated Measures ANOVA was used to evaluate the changing patterns of glucose and metabolic hormones in each group using SPSS software (SPSS for Windows, version 20, SPSS Inc, Chicago, IL, USA). The level of significance was set at $\mathrm{P}<0.05$.

\section{Results}

Alterations (mean $\pm \mathrm{SD}$ ) of serum glucose and metabolic hormones following intravenous bolus glucose administration in different metabolic states of high producing Holstein dairy cows are presented in Tables 1-3 and Figures 1 and 2. In all groups, serum glucose concentrations were increased significantly after glucose administration. The decreasing pattern of glucose was seen in late lactation and far-off dry groups and the glucose levels in these groups were significantly lower than other ones $(\mathrm{P}<0.05$; Table 1$)$. At hour zero, serum concentration of $\mathrm{T} 3$ in early lactation cows was significantly higher than other groups. The decreasing pattern of T3 concentration was detected in all studied animals following intravenous glucose infusion $(\mathrm{P}<0.05$; Table 2) but there were no significant alterations in far-off dry group. The base line values of T4 in early and mid lactation groups were significantly lower than other ones. The significant increasing pattern of T4 levels was seen in early and mid lactation cows after glucose administration $(\mathrm{P}<0.05$; Table 3$)$. There were no significant alterations in fT3 concentrations following intravenous glucose infusion in all experimental groups. The levels of this hormone following glucose administration in early lactation group were significantly higher than other groups $(\mathrm{P}<0.05$; Figure 1$)$. No significant alterations of fT4 were detected after glucose infusion in all experimental groups. The concentrations of fT4 in far-off dry cows were significantly higher than other groups at all hours $(\mathrm{P}<0.05$; Figure 1$)$. There were no significant changes in cortisol levels following intravenous glucose infusion in all experimental groups. The highest and lowest base line concentrations of cortisol were seen in mid and late lactation groups, respectively $(\mathrm{P}<0.05$; Figure 2). At hour zero, as base line level,

Table 1. Alterations (mean \pm standard deviation) of serum glucose concentrations ( $\mathrm{mg} / \mathrm{dL}$ ) following bolus intravenous glucose administration (dextrose $50 \% ; 500 \mathrm{mg} / \mathrm{kg}$ during 15 minutes) at different lactation cycles in Holstein cows (each group contains 5 cows).

\begin{tabular}{lccccc} 
Metabolic state & Hour 0 & Hour 1 & Hour 2 & Hour 3 & Hour 4 \\
Early lactation & $88.75 \pm 19.37$ & $292.01 \pm 81.03$ & $253.02 \pm 26.47 \mathrm{a}$ & $210.23 \pm 14.78^{\mathrm{a}}$ & $190.87 \pm 9.95^{\mathrm{a}}$ \\
Mid lactation & $75.15 \pm 11.06$ & $288.01 \pm 35.06$ & $230.98 \pm 24.23^{\mathrm{a}}$ & $190.20 \pm 15.85^{\mathrm{a}}$ & $153.51 \pm 9.01^{\mathrm{a}}$ \\
\hline Late lactation & $91.79 \pm 50.57$ & $255.40 \pm 87.89$ & $89.01 \pm 19.01^{\mathrm{b}}$ & $71.34 \pm 41.51^{\mathrm{b}}$ & $50.84 \pm 35.40 \mathrm{~b}$ \\
Far-off dry & $80.45 \pm 50.63$ & $310.59 \pm 69.72$ & $110.76 \pm 26.54 \mathrm{~b}$ & $100.56 \pm 25.24 \mathrm{~b}$ & $90.71 \pm 47.63 \mathrm{~b}$ \\
\hline Close-up dry & $90.47 \pm 34.60$ & $256.01 \pm 84.07$ & $220.34 \pm 61.14 \mathrm{a}$ & $180.73 \pm 57.17 \mathrm{a}$ & $150.27 \pm 48.32 \mathrm{a}$ \\
\hline
\end{tabular}

Different letters indicate significant differences among groups in each hour $(\mathrm{P}<0.05)$.

Table 2. Alterations (mean \pm standard deviation) of serum T3 concentrations (ng/dL) following bolus intravenous glucose administration (dextrose 50\%; $500 \mathrm{mg} / \mathrm{kg}$ during 15 minutes) at different lactation cycles in Holstein cows (each group contains 5 cows).

\begin{tabular}{lccccc} 
Metabolic state & Hour 0 & Hour 1 & Hour 2 & Hour 3 & Hour 4 \\
Early lactation & $141.01 \pm 22.15 \mathrm{a}$ & $133.63 \pm 34.58^{\mathrm{a}}$ & $120.22 \pm 24.53$ & $125.24 \pm 34.05$ & $138.87 \pm 30.03$ \\
Mid lactation & $122.61 \pm 8.14 \mathrm{~b}$ & $115.82 \pm 12.21^{\mathrm{b}}$ & $110.44 \pm 12.48$ & $112.45 \pm 13.89$ & $122.01 \pm 19.22$ \\
\hline Late lactation & $123.25 \pm 9.50 \mathrm{~b}$ & $123.00 \pm 9.38^{\mathrm{b}}$ & $122.25 \pm 8.46$ & $118.50 \pm 24.55$ & $123.00 \pm 20.44$ \\
Far-off dry & $128.01 \pm 20.79 \mathrm{~b}$ & $129.87 \pm 21.11^{\mathrm{b}}$ & $130.25 \pm 18.34$ & $130.42 \pm 18.88$ & $131.04 \pm 13.69$ \\
\hline Close-up dry & $126.22 \pm 17.75 \mathrm{~b}$ & $120.03 \pm 19.24 \mathrm{~b}$ & $115.24 \pm 6.79$ & $118.45 \pm 13.08$ & $124.44 \pm 39.55$ \\
\hline
\end{tabular}

Different letters indicate significant differences among groups in each hour $(\mathrm{P}<0.05)$.

Table 3. Alterations (mean \pm standard deviation) of serum T4 concentrations $(\mu \mathrm{g} / \mathrm{dL}$ ) following following bolus intravenous glucose administration (dextrose 50\%; $500 \mathrm{mg} / \mathrm{kg}$ during 15 minutes) at different lactation cycles in Holstein cows (each group contains 5 cows).

\begin{tabular}{lccccc} 
Metabolic state & Hour 0 & Hour 1 & Hour 2 & Hour 3 & Hour 4 \\
Early lactation & $3.61 \pm 0.68 \mathrm{a}$ & $3.89 \pm 0.82^{\mathrm{a}}$ & $3.99 \pm 0.44$ & $4.03 \pm 0.45$ & $4.08 \pm 0.61$ \\
Mid lactation & $3.64 \pm 0.80 \mathrm{a}$ & $3.73 \pm 1.03 \mathrm{a}$ & $3.93 \pm 0.83$ & $3.99 \pm 0.50$ & $3.97 \pm 0.41$ \\
\hline Late lactation & $4.11 \pm 0.27 \mathrm{~b}$ & $4.15 \pm 0.34 \mathrm{~b}$ & $4.15 \pm 0.46$ & $4.11 \pm 0.17$ & $4.21 \pm 0.09$ \\
Far-off dry & $4.17 \pm 0.78 \mathrm{~b}$ & $4.19 \pm 0.44 \mathrm{~b}$ & $4.39 \pm 0.62$ & $4.54 \pm 0.88$ & $4.19 \pm 0.71$ \\
\hline Close-up dry & $4.09 \pm 1.18 \mathrm{~b}$ & $4.10 \pm 1.17 \mathrm{~b}$ & $4.13 \pm 1.08$ & $3.99 \pm 0.76$ & $3.90 \pm 0.71$ \\
\hline
\end{tabular}

Different letters indicate significant differences among groups in each hour $(\mathrm{P}<0.05)$. 
serum concentrations of IGF-1 in early lactation and close-up dry cows were significantly higher than other groups. There were no significant changing patterns of IGF-1 after glucose administration in early lactation and close-up dry cows. However, the significant decreasing pattern of this hormone was detected in mid and late lactations and far-off dry groups $(\mathrm{P}<0.05$; Figure 2$)$.

\section{Discussion and Conclusions}

Glucose is a blood parameter defining the energy metabolism. The metabolism of glucose in ruminants is different from other mammals. In ruminants, volatile fatty acids from the gastrointestinal tract are the major energy source rather than direct sources of glucose. Thus, insulin plays a slightly different role in ruminants $v s$. non-ruminants, though many aspects of insulin metabolism are the same. ${ }^{2}$ Glucose is a critical nutrient in the postpartum dairy cow because glucose is used by the mammary gland for the synthesis of milk. ${ }^{16}$ Glucose is also required by a variety of other tissue types, including those involved in reproduction. ${ }^{17}$ In late lactation and far-off dry cows in this study, serum glucose concentrations were decreased near to baseline levels at $4^{\text {th }}$ hour after glucose infusion which indicate the effect of insulin on clearance of glucose (Table 1). Hence, it may be stated that these cows had not insulin resistance. However, serum glucose concentrations at final sampling in other groups were not reached to base line values. Other researchers also mentioned that there is insulin resistance phenomenon in the cows which are placed in negative energy balance.2,18 Inability to clear the and utilize the glucose in dairy cows leads to metabolic disorders such as ketosis and fatty liver, hence, providing the glucose source in these animals may protect them from the metabolic problems. ${ }^{2}$

Thyroid gland produces the thyroid hormones containing $\mathrm{T} 3$ and its prohormone, $\mathrm{T} 4$ which are tyrosine-based hormones. Thyrotropes of the anterior pituitary gland secrete thyroid stimulating hormone and this hormone regulates the production of $\mathrm{T} 3$ and $\mathrm{T} 4$ by follicular cells of the thyroid gland. T4 is the major circulating thyroid hormone which has a longer half-life than T3. T4 is changed to the active $\mathrm{T} 3$ and $\mathrm{T} 3$ is more potent than $\mathrm{T} 4$. Circulating fT3 and fT4 represent the amount of T3 and T4 that are not bound to proteins. Evaluating the fT3 and fT4 can be used to assess and manage disorders of the thyroid gland. 19

Thyroid hormones are primarily responsible for metabolism regulation. They increase the metabolic rate, change protein synthesis, reg- ulate osteoblasts and nervous system maturation and increase the sensitivity to catecholamine. The proper circulating levels of thyroid hormones are necessary to develop and differentiate all of the cells. These hormones also are responsible for regulation of protein, fat, carbohydrate and vitamin metabolism. Numerous physiological, pathological and pharmacological stimuli influence thyroid hormone metabolism. ${ }^{20,21}$

The results of the present study showed that serum levels of thyroid hormones were changed following glucose infusion. The significant and obvious changing patterns of T3 and $\mathrm{T} 4$ were detected in the cows which were placed in negative energy balance. Hence, it may be stated that providing the source of energy, as bolus intravenous glucose, could resolve the negative energy balance and change serum levels of thyroid hormones. Djokovi et al. detected the hypothyroidal status in ketotic cows and the low circulating glucose concentration in these cows. ${ }^{22}$

Growth hormone is in control of metabolism in the dairy cow in all stages of lactation. ${ }^{23}$ The effect of growth hormone on lactation is discussed to be only partly direct and instead mediated by IGF-1.24,25 Receptors for IGF-1 can be found in all mammary cells and release of IGF-1 is stimulated by binding of growth hormone to hepatocytes in the liver, ${ }^{12}$ which is the main source of circulating IGF-1. ${ }^{26}$

The concentration of IGF-1 can be seen as an indicator of the metabolic state of the dairy cow. ${ }^{27}$ Abribat et al. showed that the levels of IGF-1 are lower at the start of lactation and increase during the whole lactation, inversely related to milk yield. ${ }^{24}$ The results of the current study showed the decreasing patterns of IGF-1 in all studied animals. Other researchers also mentioned acute decreases in circulating IGF-1 in response to increases in insulin or glucose. 15 It may be suggested that glucose had the obvious effect on metabolism of this hormone in dairy cows. Damptey et al. showed that IGF-1 concentration was positively correlated with insulin $(\mathrm{r}=0.377 ; \mathrm{P}<0.001)$ and glucose $(r=0.249 ; \mathrm{P}<0.05) .28$ This suggests that energy status or energy intake may regulate plasma concentrations of IGF-1. Ciccioli et al. ${ }^{29}$ also observed a positive correlation between plasma IGF-1, insulin and glucose concentrations in Angus x Hereford primiparous cows.

Cortisol is the major stress hormone produced by the adrenal glands in the ruminant. Based on our finding the highest levels of cortisol were seen in mid lactation period which the cows had the high milk yield. It may be suggested that the negative energy balance in this period can be considered as a stress factor to induce the elevation of circulating cortisol. Hunter et al. mentioned that during the transition period, cortisol is elevated prior to, during and following parturition, signifying an increased release of the adrenocorticotropin (ACTH). ${ }^{30}$ A normal response to stressful conditions is activation of the hypothalamic-pituitary-adrenal axis. ${ }^{31}$ Physiological stressors cause the release of the hypothalamic corticotropin releasing factor which increases ACTH. ${ }^{32}$ During the periparturient period, stressors are above what the cow normally experiences, eliciting an increased release of ACTH. 30 Cortisol is the major glucocorticoid produced by the adrenal cortex in response to stressful stimuli and also plays a role in glucose regulation. ${ }^{31}$ However, no significant alterations of cortisol were detected in all experimental groups following glucose administration.

In conclusion, it may be suggested that bolus intravenous glucose infusion could influence the metabolic hormones in high producing Holstein dairy cows. Alterations of metabolic hormones following bolus intravenous glucose administration indicated that glucose is an important direct controller of metabolic interactions and responses in dairy cows during different physiological states.

\section{References}

1. Aschenbach JR, Kristensen NB, Donkin SS, et al. Gluconeogenesis in dairy cows: the secret of making sweet milk from sour dough. IUBMB Life 2010;62:869-77.

2. De Koster JD, Opsomer G. Insulin resistance in dairy cows. Vet Clin North Am Food Anim Pract 2013;29:299-322.

3. Reynolds C, Aikman P, Lupoli B, et al. Splanchnic metabolism of dairy cows during the transition from late gestation through early lactation. J Dairy Sci 2003; 86:1201-17.

4. Young J. Gluconeogenesis in cattle: significance and methodology. J Dairy Sci 1977;60:1-15.

5. Allen MS, Bradford BJ, Harvatine KJ. The cow as a model to study food intake regulation. Annu Rev Nutr 2005;25:523-47.

6. Fiore E, Gianesella M, Arfuso F, et al. Glucose infusion response on some metabolic parameters in dairy cows during transition period. Archiv Tierzucht 2014;57:1-9.

7. Grummer RR, Mashek DG, Hayirli A. Dry matter intake and energy balance in the transition period. Vet Clin North Am Food Anim Pract 2004;20:447-70.

8. Reist M, Erdin D, Von Euw D, et al. Estimation of energy balance at the individual and herd level using blood and milk traits in high-yielding dairy cows. J Dairy Sci 2002;85:3314-27.

9. Nikolic J, Samanc H, Begovic J, et al. Low peripheral serum thyroid hormone status 
independently affects the hormone profile of healthy and ketotic cows during the first week post partum. Acta VeterinariaBeograd 1997;47:3-13.

10. Nixon DA, Akasha M, Anderson R. Free and total thyroid hormones in serum of Holstein cows. J Dairy Sci 1988;71:115260 .

11. Blum J, Kunz P, Leuenberger $\mathrm{H}$, et al. Thyroid hormones, blood plasma metabolites and haematological parameters in relationship to milk yield in dairy cows. Anim Sci 1983;36:93-104.

12. Tucker H. Hormones, mammary growth, and lactation: a 41-year perspective. J Dairy Sci 2000;83:874-84.

13. Huntington G, Harmon D, Richards C. Sites, rates, and limits of starch digestion and glucose metabolism in growing cattle. J Anim Sci 2006;84:E14-24.

14. Zhao FQ, Keating A. Expression and regulation of glucose transporters in the bovine mammary gland. J Dairy Sci 2007;90:E76-86.

15. Lucy M, Escalante R, Keisler D, et al. Short communication: glucose infusion into early postpartum cows defines an upper physiological set point for blood glucose and causes rapid and reversible changes in blood hormones and metabolites. $\mathbf{J}$ Dairy Sci 2013;96:5762-8.

16. Bell AW. Regulation of organic nutrient metabolism during transition from late pregnancy to early lactation. J Anim Sci 1995;73:2804-19.
17. Berlinguer F, Gonzalez-Bulnes A, Contreras-Solis I, et al. Glucogenic supply increases oocyte developmental competence in sheep. Reprod Fertil Dev 2012;24:1055-62.

18. Pires J, Souza A, Grummer R. Induction of hyperlipidemia by intravenous infusion of tallow emulsion causes insulin resistance in Holstein cows. J Dairy Sci 2007;90:273544.

19. Yen PM. Physiological and molecular basis of thyroid hormone action. Physiol Rev 2001;81:1097-142.

20. Tan K, Shiu S, Kung A. Effect of thyroid dysfunction on high-density lipoprotein subfraction metabolism: roles of hepatic lipase and cholesteryl ester transfer protein 1. J Clin Endocrinol Metabol 1998;83:2921-4.

21. Taylor AH, Stephan ZF, Steele RE, Wong NC. Beneficial effects of a novel thyromimetic on lipoprotein metabolism. Mol Pharmacol 1997;52:542-7.

22. Djokovi R, Šamanc H, Jovanovi M, Nikoli Z. Blood concentrations of thyroid hormones and lipids and content of lipids in the liver of dairy cows in transitional period. Acta Veterinaria Brno 2007;76:525-32.

23. Sjaastad OV, Hove K, Sand O. Physiology of domestic animals. Oslo: Scandinavian Veterinary Press; 2010.

24. Abribat T, Brazeau P, Davignon I, Garrel DR. Insulin like growth factor I blood levels in severely burned patients: effects of time post injury, age of patient and severity of burn. Clin Endocrinol 1993;39:583-9.

25. Svennersten-Sjaunja K, Olsson K. Endocrinology of milk production. Domest Anim Endocrinol 2005;29:241-58.

26. Akers RM. Lactation and the mammary gland. Ames: Iowa State Press; 2002.

27. Taylor V, Cheng Z, Pushpakumara P, et al. Relationships between the plasma concentrations of insulin-like growth factor-I in dairy cows and their fertility and milk yield. Vet Rec 2004;155:583-8.

28. Damptey J, Obese F, Aboagye G, Ayizanga R. Correlations among concentrations of some metabolic hormones and nutritionally-related metabolites in beef cows. Online J Anim Feed Res 2013;3:176-80.

29. Ciccioli N, Wettemann R, Spicer L, et al. Influence of body condition at calving and postpartum nutrition on endocrine function and reproductive performance of primiparous beef cows. J Anim Sci 2003;81:3107-20.

30. Hunter D, Erb R, Randel R, et al. Reproductive steroids in the bovine. I. Relationships during late gestation. J Anim Sci 1970;30:47-59.

31. Christison G, Johnson H. Cortisol turnover in heat-stressed cows. J Anim Sci 1972;35:1005-10.

32. Collins KJ, Weiner JS. Endocrinological aspects of exposure to high environmental temperatures. Physiol Rev 1968;4):785839 . 